\title{
Green governmentality: insights and opportunities in the study of nature's rule
}

\section{Stephanie Rutherford*}

\author{
Faculty of Environmental Studies, York University, Toronto, Ontario, Canada
}

\begin{abstract}
This article seeks to unpack notions of governmentality by reading it through the case of nature. By highlighting three key aspects of governmentality - its analytics of power, biopolitics, and technologies of the self - I argue that this approach presents a promising theoretical trend for those who study nature and its rule. However, there have been critiques leveled at this approach which must be considered. Using examples drawn from human/non-human interactions, I explore how the governmentality literature needs to be made more complex and attune to difference. In the final analysis, I argue that the concept of governmentality is not only an effective tool for geographers, but that geography provides a particularly insightful lens with its attention to spatiality, scale, territory and human/non-human relations that enrich the analysis of the making of governable spaces.
\end{abstract}

Key words: Foucault, green governmentality, human geography, nature.

\section{Introduction}

governmentality marks the emergence of a distinctly new form of thinking about and exercising of power in certain societies. (Dean, 1999: 19)

Governmentality. The very word makes some scholars tremble with anticipation and leaves others cold at the thought of inscrutable text and a high level of abstraction. But what is its utility for geographers? And what might geographers add to the concept of governmentality? This article is an attempt to enter the murky terrain of governmentality, to tease out its insights and indicate its usefulness as a promising theoretical avenue for geographers who take up the questions about 'nature' and human/nonhuman interactions.' Using nature as a lens to narrow the debate, I draw on specific examples or vignettes to argue that the ways in which it is conceived, acted upon and managed may be often read as a forms of governmentality, where grids of power, technologies of the self, and discursive regimes of the environment are enacted. What I am not doing is a comprehensive analysis of green governmentality. That is beyond the scope and intent of this paper. Instead, I am drawing on focused examples to assert that governmentality offers promising analytical terrain to geographers who make it their business to

*Email: stephier@yorku.ca 
interrogate the intersections between nature, power and society. Nevertheless, the enthusiasm for this theoretical construct must be tempered by several well-placed critiques. In particular, critics have noted that governmentality is often deployed in ways that belie its original formulation, generating analyses under the banner of Foucault which are decidedly 'un-Foucauldian'. In select parts of the governmentality literature, rule appears as a completed project, simply applied to a passive populace. Moreover, some of the work in this field has ignored the complicated realities of social location, imagining that all bodies are incorporated into systems of rule in the same ways. Further, the research on governmentality often focuses on state regulation and its impacts and effects on the population, and yet neoliberal governance has made it such that there are multiple sites of governing. Given these critiques, a central part of my call for geographers of nature to take up this analytic of power comes with the caveat that it is done with attention to the ways in which governing is always becoming, necessarily uneven, often contested, and sometimes exercised outside of the state. I argue that critical geographers are already well positioned to answer this call.

I begin by outlining and discussing the scholarly work concerning governmentality, in part returning to Foucault to explore his original insights as well as exploring some of his interlocutors in geography. I then go on to highlight three key aspects of governmentality - its analytics of power, biopolitics, and technologies of the self - which have particular importance for the circulation of green governmentality. I turn to the critiques of this theoretical framework, using examples drawn from human/non-human interactions to explore how the governmentality literature needs to be made more complex and attune to difference. In the final analysis, I argue that the concept of governmentality can be an effective tool for geographers but also that geography provides a particularly insightful lens with its attention to spatiality, scale, territory and human/non-human relations that enrich the analysis of the making of governable spaces.

\section{Governmentality or the 'conduct of conduct'}

The literature on governmentality has exploded in recent years with a wide array of scholars taking up this particular way of analyzing power. For example, studies have applied governmentality to neoliberal rationality (Gordon, 1991; Barry et al., 1996; Dean, 1999; Lemke, 2001), colonial rule (Scott, 1999), the production of insurance and risk (Hacking, 1990; Ewald, 1991) and the plethora of self-help and self-improvement programs that have emerged (Cruikshank, 1996). Some geographers have also entered the fray with cogent work on population geography (Philo, 2001; Legg, 2005), the biopolitical projects of census-taking and statistics (Brown and Boyle, 2000; Hannah, 2000; 2001), the construction of agricultural spaces (Murdoch and Ward, 1997) and, of course, the construction of nature (Darier, 1996; 1999; Luke, 1997b; 1999; Rutherford, 1999; 2002; Braun, 2000; Demeritt, 2001; Bäckstrand, 2004). Indeed, geographers have been particularly important in spatializing governmentality (cf. Moon and Brown, 2000; Raco, 2003), remarking upon the ways in which rule is organized and circulated through particularly situated bodies and places. The upsurge in interest around this concept has provided fruitful terrain for understanding how governmentality might be operationalized. However, it has also meant that different people have applied the concept in very different ways. For example, some scholars chart the ways governmentality works to produce biopolitical knowledge of the population (Legg, 2005). Others highlight how colonial rule is a complex affair, more nuanced than simply western domination (Howell, 2004). Some work (though significantly less) focuses on the formation of the subject (Gibson, 2001; Mitchell, 2003) and pastoral power (Blake, 1999). Some scholars talk about contragovernmentality (Luke, 1996) while others take a neo-Foucauldian approach (MacKinnon, 
2000). Given the plurality of approaches, I find it useful to return briefly to Foucault to discuss the emergence and functioning of governmentality, applying the original concepts to a reading of the governing of nature.

In Discipline and punish (1995), Foucault argued that the historical root of the sovereign's power was in death, or more properly, the juridical means to take away life was one of the defining characteristics of the exercise of power. In this articulation of sovereign power, the public execution was paramount. It served the specific purpose of producing the truth of power through juridical punishment meted out by the sovereign. However, the visibility and obvious location of this power made it vulnerable to both the charge of oppressiveness and hence, to resistance, where the public which was to be governed via the spectacle sometimes took the side of the criminal rather than the king. The instability of the sovereign modality of power as exemplified through the 'spectacle of the scaffold' (1995: 49) was but one impetus for the rethinking of political rationalities and the rise of governmentality.

The questioning of sovereign power began a series of transformations in ideas about rule. Foucault (1991) argues that the ideas about the exercise of power began to change in the sixteenth century, fueled by the confluence of several shifts in thought: debate about the reason of the state; ideas around the knowledge of the population (statistics); the Reformation and the utility of pastoral power; and, theories on self-government. Thus, different questions started to emerge about the nature of governing itself:

How to govern oneself, how to be governed, how to govern others, by whom the people will accept being governed, how to become the best possible governor - all these problems, in their multiplicity and intensity, seem to me to be characteristic of the sixteenth century. (Foucault, 1991: 87)

Building over the course of two centuries, the refashioning of the idea of government was bolstered by the demographic boom of the eighteenth century, which reinforced the need to manage the population itself. Demographics, statistics and insurance established new power/knowledge formations that placed the individual into a larger population, whose characteristics could be measured, assessed and managed. Making both the individual and population objects of knowledge for government is the hallmark of modern rule, where the aim is to strengthen the state through the exercise of tactics and the construction of knowledge rather than the imposition of law (Foucault, 1991; 1994; 2003). Governing becomes the construction of certain truths and their circulation via normalizing and disciplining techniques, methods, discourses and practices that extend beyond the state and stretch across the social body (Foucault, 1990). However, this does not signal the death of sovereign power. Rather, what we see in this new modality of governing is a triad of sovereignty, discipline and government, where each is reformed, 'within the concern for the population and its optimization (in terms of wealth, health, happiness, prosperity, efficiency), and the forms of knowledge and technical means appropriate to it' (Dean, 1999: 20).

What makes this approach different to other studies of rule? What new insights does it provide that are, for example, missing in Gramscian hegemony theory or Putnam's theories of governance? Is it simply another label to talk about the same old thing? The difference, as Dean indicates is the how questions that characterize Foucault's work. Dean asserts that four dimensions are examined through the analysis of governmental rationality that make this approach different from the others. They are its attention to: 'characteristic forms of visibility, ways of seeing and perceiving'; the production of regimes of truth which circumscribe how the world is apprehended; the ways in which particular technologies and experts are constructed and deployed; and the formation of particular kinds of bodies and subjects (1999: 23). It is through asking how these four dimensions are iterated and re-iterated 
that allows scholars to locate social, cultural, ecological and a host of other discourses and practices as power-infused relations rather than innocent endeavors.

Recent studies by geographers have taken up the how questions outlined above, putting flesh on these particular theoretical bones. Legg's (2005) work, for example, has provided a scaled analytical frame through which to understand the operation of a biopolitical concern in colonial India. Thus, Legg asserts that governmentality often takes place through a multiplicity of scales: the subject, territories, the nation, the population and the globe (2005: 145-46). But Legg does not stop here. He then identifies five 'dimensions to regimes of government' (2005: 147) which one can read through programs of rule: particular epistemes or ways of thinking; the construction of some subjectivities and the disavowal of others; the picturing and apprehending of reality; strategic technologies of rule; and the values or 'ethos' of a particular government (2005: 147-49). By breaking down the 'conduct of conduct' in relation to biopolitics, Legg's work is useful in two respects. First, it allows us to consider the different scales through which governmentality is constructed and circulated. Second, it provides us with a methodological map to identify and explore governmentality.

Through the work of Legg and others, we can see that governmentality offers geographers a wealth of opportunity for analysis. First, it seeks to take apart the self-evidence or truth of governing, revealing its historical contingency and entrenchment in the social, political, economic, cultural and non-human contexts which produce it. Further, it de-centers the state as seat of power: power bleeds across the social body in such a way that governing occurs in multiple sites and through a myriad of techniques. And finally it asks the 'how' questions that Dean emphasizes:

This approach thus stands in contrast to theories of government that ask 'who rules?,' 'what is the source of that rule?' and 'what is the basis of its legitimacy?' An analytics of government brackets out such questions not merely because they are stale, tiresome, unproductive and repetitive. It does so because it wants to understand how different locales are constituted as authoritative and powerful, how different agents are assembled with specific powers, and how different domains are constituted as governable and administrable. (Dean, 1999: 29)

The strength of this sort of interrogation is it allows geographers to make different kinds of assertions about the ways in which modern rule operates: that power is exercised in multiple sites, through different discourses, and often outside the traditional boundaries of the state. Further, that it forms nexuses of power/knowledge that shape how we come to understand things as the truth. Finally, that it is both constituted by and of certain subjectivities. Following Dean and Legg, then, the next section looks at the ways in which particular regimes of truth, subject positions, representations of reality, practices of rule, and kinds of morality are formed through the circulation of green governmentality.

\section{Green governmentality and the saving of nature}

\begin{abstract}
Environmental problems similar to 'madness', 'sexuality' and 'criminality' are not 'out there' in a pure and unmediated form, but various techniques, procedures and practices construct and produce these fields in such a way that they become both objects for knowledge and targets for regulation. (Bäckstrand, 2004: 703)
\end{abstract}

Nature was never high on Foucault's list of priorities - in fact, he indicated a definite distaste for it. In one biographical account, he is said to have shunned a natural vista pointed out by a friend, saying, 'My back is turned to it' (Éribon in Darier, 1999: 6). This might give some indication as to why nature was rarely included in Foucault's analyses. Rutherford (2002) reminds us, however, that the government of population must include the very environment from which humanity subsists. Indeed, nature - claims on the land, the construction of wilderness, ideas of human nature, human/non-human interaction - is 
one area in which the messy politics of representation, articulation, essentialism and discursive construction come to the fore, making it a particularly interesting site to interrogate the exercise of power (Moore et al., 2003). The ways in which the environment is constructed as in crisis, how knowledge about it is formed, and who then is authorized to save it become important for understanding the ways that the truth about the environment is made, and how that truth is governed.

The saving of nature is often taken for granted as an innocent endeavor, never implicated in relations of power and a noble exercise for the good of all life. Often underpinned by 'the one-world discourse', the basis of this assertion is the notion that we are all connected through our intertwined ecological fate (King, 1997: 1). Thus, what emerges is a 'dominant storyline of the "fragile earth" under stress from human action and in need of care and protection from an imagined global community' (Macnaghten, 2003: 65). This way of producing the environment and its resources as bounded elicits the discourse of the limits of the earth, a central tenet of environmental politics (Dobson, 1990). The production of this kind of truth about nature necessitates its regulation, management and governing.

Corporations, all levels of government, scientists, United Nations organizations, and global think tanks have all inserted themselves into the game of speaking for nature. Typified by the sustainable development discourse, these different actors work to produce knowledge about the earth and its resources that cast it as manageable (Hajer and Fischer, 1999). Within this discursive regime we must also situate the environmental organizations, which shape the truth about nature, and seek to regulate and ameliorate its (ab)use. As Barry et al. (1996) note, neoliberal political rationality necessitates, in part, a marked withdrawal or reconfiguring of the state and its functions. As a result, some previously state-based responsibilities have been shunted onto the market, quasi-private sector or the nebulous catchall, civil society. In this vein, we see the birth of public-private partnerships, where non-governmental organizations, corporations and the state work together to manage the 'problems' of society. The administration of parts of the penal system, the construction of social housing, and the provision of health care have all started to be reconfigured in this way in different western countries. Environmental management is no different, and regulatory, policy-making and monitoring functions have been added to the purview of some larger environmental NGOs. Indeed, there are now more than 100,000 environmental organizations worldwide working to regulate and manage nature (Emel, 2002). Further, we see the emergence of corporations acting as environmental funding agencies, as initiatives like Disney's Wildlife Conservation Fund attests. ${ }^{2}$ The result of both the number of organizations and their broadened political function has meant that 'most environmentalist movements now operate as a basic manifestation of governmentality' (Luke, 1999: 121). Given this assertion, what aspects of governmentality might prove most useful to those who examine environmental politics? I argue that there are three: analytics of power, biopolitics and the making of environmental subjectivities.

\section{The analytics of power}

One of Foucault's most lasting contributions to the intellectual landscape has been his analysis of power. In a counterintuitive move, Foucault decries the traditional understanding of power as domination and repression. Instead he argues that although power does discipline and control, one of its central features is its productiveness: 'In fact, power produces; it produces reality; it produces domains of objects and rituals of truth. The individual and the knowledge that may be gained of him belong to this production' (Foucault, 1995: 194). But in its production of knowledge, truth and subjectivities, Foucault (1980) is at pains to elucidate that power is not possessed or held, but rather circulates via networks that work through and produce different bodies, 
discourses, institutions and practices. Foucault makes this more explicit by mapping out four characteristics of power in The history of sexuality, vol. I (1990: 94-96). First, that power is everywhere, or more properly it is exercised from and through countless sites, practices, agents, discourses and institutions. Following this, he asserts that power cannot be seen as emanating only from above. Rather, it "comes from below' (1990: 94), working through webs of different power relations. Foucault thus complicates the supposed binary between those who govern and those who are governed. He goes on to argue that power is intentional but non-subjective. In doing so, he alerts us to the fact that, while there are goals behind the exercise of power rooted in discourse, these goals cannot be ascribed to decisions, whims or desires of particular people. Lastly, Foucault makes the assertion that where there is power there is always resistance, but this resistance cannot be seen outside of power. As such, he asks us to think about resistance differently, as not anterior to power, but a component of it.

If we take seriously these notions on the exercise and circulation of power, then we can see that the art of governing is a complex business, operating though assemblages to produce the governable and the normalized. Examining power in this way opens up the field of possibility to talk about particular kinds of environmentalism, for example, as a site for the exercise of certain kinds of power. One such form that had received the bulk of attention in the literature on green governmentality is disciplinary power. As Luke has noted, disciplinary power undergirds the environmentalist project where places are reconfigured and reimagined as sites in need of intervention (Luke, 1998). He offers the example of the Worldwatch Institute, which he asserts operates through the production of discourses of global sustainable development and functions as one of the main actors, in concert with government and business, in the formation of green governmentality (Luke, 1997a). Producing a document every year entitled
'The State of the World', Worldwatch gathers statistics on global population trends, biodiversity loss, environmental security, and climate change (among many others), producing an authoritative measurement, assessment and forecast of the earth's resources (cf. Renner, 2005). This is knowledge of the population at its zenith. King (1997) echoes Luke's observations, pointing to the panoptic nature of the green project, where the monitoring of particular populations (often of the Global South) has become a key feature in the establishment of notions of global environmental security. From these examples, geographers can take a number of insights about the operation of modern power. We can see that power is capillary and diffused, not only rooted in the state but found in global think tanks, environmental organizations and even corporations. Further, they show the ways in which dichotomies between power and resistance in environmental politics are facile, and point to how they can, and often are, co-produced. Finally, that power is not only about repression but also about productivity - the power to produce knowledge about the environment is key in formulating the terms of its management. But this is not a power which operates outside of spatiality. Indeed, what the Worldwatch Institute, among other organizations, does is produce the truth of a global environment under threat, rescaling the debate upward to erase specificity and difference.

\section{Biopower/biopolitics}

Unlike his earlier work in Discipline and punish (1995) where he concerns himself the construction of docile bodies, it is in Foucault's later work in The history of sexuality, vol. 1 and his lectures at the Collège de France where he turns his attention to the concept of biopolitics. In contrast to disciplinary power, biopower takes root through the regulatory controls of the population (rather than the individual) through the management of life birth rates, life expectancy, health and wellbeing - all indicators of the population which began to increasingly matter to those who 
govern (1990). As Rabinow states, biopolitics 'brought life and its mechanisms into the realm of explicit calculations and made knowledge-power an agent of the transformation of human life' (1984: 17). It is through this management of the conditions of life that those who govern can shape how the population conducts itself to the best end for the continuation of that government. It is important to recognize that, even though there is this distinction between disciplinary and biopower, they work in tandem: one individualizing and the other totalizing - governing the conduct of each and all.

Green governmentality theorists propose that Foucault's work can be centrally important in analyzing the production and circulation of discourses of nature if we extend the concept of biopower to include all life. As Darier (1999) has argued, biopolitics can be reframed as 'ecopolitics' where concern for the conditions of the national population is subsumed under more intensified attempt to manage the planet's environment. The most telling way that biopolitics has been operationalized is through the use of science to tell the truth of the environment - its characteristics, its usefulness and, eventually, its crisis.

Geographers have been particularly astute in examining the ways science has been implicated in the production of national (and often colonial) natures. Braun's (2000) historical account shows the role of geology in bringing the Canadian west into view as a landscape of calculable resources. By charting George Dawson's journey to the Queen Charlotte Islands, Braun indicates that Dawson engaged in a process of 'reterritorialization' through representation, erasing the presence of First Nations inhabitants by mapping the islands instead as a site for mineral extraction under Canada's emerging national rule. Dawson's efforts remade the Queen Charlotte Islands as only a 'geological landscape' - charted, diagrammed, sketched and made intelligible for the political and economic aims of an emerging state (Braun, 2000: 15). Demeritt (2001) also takes up these notions in his examination of the production of the national forest in the Progressive Era of the United States. He argues that through biopolitical practices of assessment, such as the generation of statistical data and graphic representations, the US national forest came into being as both an intelligible and calculable entity, which in turn 'provided both the context and impetus for the governmental institution of scientific conservation and the far-reaching reconstruction of nature, civil society, and the state that scientific conservation entailed' (2001: 433). Through these endeavours of mapping, measuring, organizing, quantifying and above all representing particular aspects of nature, these authors show how the environment is brought into being, becomes an object of analysis and its management a key aspect of governance.

Murdoch and Ward's (1997) study of the making of the national farm in pre-second world war Britain also examines the operation of biopower through the production of statistics. In an article which brings actor-network theory and governmentality together in conversation to useful purpose, they show how the notion of the British national farm was made via its representation through statistics which 'rendered agriculture visible and permitted its characterization as an economic sector' (Murdoch and Ward, 1997: 307). Through the collection of survey statistics about farms and farmers, the state produced the 'fictive space known as the national farm' (1997: 321) which was stripped of its place-based specificity and instead was made knowable as one part of a larger national economy. This allowed the state to govern from a distance, using policy and statistical evidence to influence how farmers saw themselves, their farms, and their role in the economy of Britain. In this way, the British agricultural sector was brought into being, and its representation through statistics came to be its truth.

These kinds of analyses present important opportunities for understanding how knowledge about the environment continues to be generated today. Rose (1996), in discussing the centrality of expertise in governmentality, has 
argued that the authority and legitimacy generated by the supposed objectivity of science produced new kinds of knowledge/power and techniques for regulation. This is no different in the case of the earth sciences. In one of Foucault's rare references to nature, he asserts: '[b]ut in fact, ecology also spoke a language of truth. It was in the name of knowledge concerning nature, the equilibrium of the process of living things, and so forth' (Foucault in Darier, 1999: 4). ${ }^{3}$ Biologists, botanists, geologists, physicists and, of course, ecologists, have all asserted their authority in speaking about the environmental crisis. Indeed, it is through the spectacle of events such as the various Earth Days and Summits, international climate change conferences and the World Summit on Sustainable Development, for example, that the truth and legitimacy of the science of ecology is performed and reinforced (Peace, 2002). Further, these global meetings and their attendant observations, predictions, calculations and forecasts make the validity and credence of ecology obvious: 'what was unknown has become fully knowable; what was mysterious is now readily imaginable; and the whole has become eminently governable' (Peace, 2002: 536-37). To know, to measure, to assess, to document risk, and propose its necessary remedies are the tools that the environmental sciences use to construct and circumscribe the problems and their self-evident solutions.

This governability of nature comes through in the scientific discourse related to the carrying capacity and limits of the earth (Rutherford, 1999; 2002; Luke, 1999). What this discourse of limits implies is its manageability: the resources of the earth can be rationalized, indexed, measured, assessed and made better through the application of various technologies and modalities of rule. Luke argues this point succinctly with regard to the compelling discourse on sustainable development: 'Encircled by grids of ecological alarm, sustainability discourse tells us that today's allegedly unsustainable environments need to be disassembled, recombined and subjected to the disciplinary designs of expert management' (1999: 142). Thus, ecology and the earth sciences cannot be seen as unimplicated in politics. Rather, they have become fundamental to the production of regimes of governmentality that create the conditions of possibility to speak about nature as something in desperate need of governing by particularly located experts. Thus, ecology works as a power/knowledge regime, producing the truth about nature, the way it can be told, and by whom.

\section{Technologies of the self and} subject formation

While geographers have critically engaged with notions of political rationality, power and biopolitics, considerably less work has been done on the ways in which governmentality works to produce normalized subjectivities (for notable exceptions see Gibson, 2001; Mitchell, 2003; Desbiens, 2004; Howell, 2004). ${ }^{4}$ Yet, an important part of the governing of nature is examining how subjects encounter and understand themselves within it. Here again we see Foucault's fascination with the multiple forms of power; he attends not only to subject formation as a repressive process, but also its productiveness, where, 'individuals are the vehicles of power, not its points of application' (1980: 98). One part of the making of certain subjectivities is through technologies of the self. These are the ways in which people choose to become certain kinds often more virtuous kinds - of subjects, through the application of techniques for improvement. As Rose has noted of the neoliberal subject, there is a call to:

\footnotetext{
Become whole, become what you want, become yourself: the individual is to become, as it were, an entrepreneur of itself, seeking to maximize its own powers, its own happiness, its own quality of life, through enhancing its autonomy and then instrumentalizing its autonomous choices in the service of its lifestyle. (Rose, 1996: 158)
}

This works in very particular ways, but at its base is the notion of incompleteness: that 
there is something else we need to be, do, or have to become a coherent and selfactualized subject (Miller, 1993). And in large part it functions through a kind of pastoral power in a quasi-therapeutic relationship, where the expert gives kindly advice to the subject in the journey that strives for completion. It is through the examination of conscience, the process of confession to an expert and the renunciation (or ascetic rejection) of behaviour that might be understood as 'abnormal' that the subject's conduct can be corrected and the individual can embark on his or her path to self-fulfillment. The attractive possibilities provided through these technologies of the self are manifold. First, it suggests that we are autonomous subjects who are able to intervene in our lives and thus change them. Further, it inscribes desire on our bodies and selves - many people want to be better and do better in the world. And these technologies for improvement are often broken down into manageable steps for the quick reference and easy application. For example, many environmental organizations provide tips on how to be a better environmental citizen in manageable and easy steps, such as turning off lights, composting, fixing leaky faucets and using cloth bags for shopping. Greenpeace International dedicates a section on its website to 'Green tips you can practice everyday' (Greenpeace Canada, no date). The Natural Resources Defense Council (2005) provides a 'guide to greener living'. The World Wildlife Fund (no date) details 'How you can help: at home, out shopping and at work'. I do not mean to intimate that these strategies of consumer responsibility are misguided or ineffectual; indeed, I would agree that these are the kinds of thing that people in the North must incorporate into their lives. But what these quick fixes elide are the ways in which environmental destruction may have less to do with the individual (and how she shops!) and more to do with sanctioned actions of governments and industrial polluters - fossil fuel industries, extractive corporations, the promotion of nuclear energy, the ecological effects of militarism, and so on. Rather, the responsibility for the environment is shifted onto the population, and citizens are called to take up the mantle of saving the environment in attractively simplistic ways. This allows for the management, self-surveillance and regulation of behaviour in such a way that lays claim to the kind of subjectivity that those who are environmentally conscious wish to have, and the governing of said subjectivity which does little to address the neoliberal order which contributes to environmental problems. In terms of becoming good environmental citizens, then, we know that there are virtuous and immoral ways to encounter nature, good and bad solutions to environmental problems and the tools for individuals to be responsible for their actions are defined already - we must only seek to apply them to our lives (Luke, 1997a). Thus, as Cruikshank's (1996) work on the self-esteem movement in California has pointed out, rather than power being imposed from outside, this is the kind of power we exercise on ourselves.

Arun Agrawal (2005) has been particularly adept in examining how environmental subjectivities are constructed in and through regulatory communities in Kumaon, India. Through what he terms 'intimate government' (2005: 193), villagers in this area take up the subject position of environmental citizen through a process of relocating (or devolving) decision-making power to the locality. In this way, many villagers feel empowered to manage their own environments, engaging in conservation practice and monitoring their own behavior and, significantly, the behavior of others. In another example, Darier's (1996) work on Canada's Green plan argues that this environmental policy certainly works through its attention to disciplinary practices, highlighting the nature of drills and repetition in recycling programs to prove his point. He cites the ways in which this policy produces knowledge about the environment and constructs an environmental citizenry through the use of educational programs. The construction of an 
environmental citizen in both of these cases indicates the operation of a micro-politics of power, where self-construction becomes essential to the governing of environmental risk. The seductiveness particular to the environmentalist project of self-regulation is that it can come with the possibility of claiming an identity of innocence and resistance to power. As Foucault has so insightfully remarked, there is pleasure in 'speaking truth to power' (1990). In naming that which oppresses, in testifying about its domination, in critiquing those who rule, there is often a positioning of oneself anterior to, or outside of, power.

\section{Critiques of governmentality: the need for geographical insights}

The previous sections have tried to sketch out some of the ways in which the concept of governmentality might be particularly useful to geographers who study the governing of nature or environmental politics. However, this does not mean that notions of governmentality should be applied without caution. In this section, I will look at some of the ways in which this body of literature needs to be questioned, made messier, and informed by a critical perspective. I will also suggest that geographers are well positioned to engage in the kind of revisioning.

One of the more troubling aspects with some of the literature on governmentality is that the programmes, policies, practices and techniques of rule interrogated by many scholars often appear as completed projects. The work of O'Malley et al. (1997) has been particularly helpful in deconstructing these unified applications of governmentality. These authors note that there is a sense that governmentality operates and circulates as it is intended to with very little deviation, or if deviation is present, it is cast as a failure. In what they term 'the messy actualities of social relations' (1997: 509), O'Malley et al. point out that much of the governmentality literature has limited its field of analysis by examining only the abstract operations of political rationalities. In this way, they have devalorized the material realities of how rule is administered. This abstraction glosses over the ways in which strategies can, and often do, go astray when they meet their target of application. It ignores the interstitial slippages that can occur in the application of power and the moments of instability that emerge as a result. This kind of work glosses over the ways in which the construction and performance of rule is always the result of contested engagement (O'Malley et al., 1997). Governing does not arise as a fully realized project, but is debated, revised, fine-tuned and continuously in need of re-articulation. Some geographers have taken up the notion of the unfixity of rule. For instance, Howell's (2004) work on prostitution in colonial Hong Kong has shown that governance was never a completed project but, rather, the negotiation between the British desire to rule and Chinese cultural practice. In another example, Watts' (2003; 2004) recent explorations of authoritarian governmentality in Nigeria have indicated that some spaces become ungovernable, where transnational corporations, the state, indigenous populations, youth coalitions and local communities vie for the profits and meaning that oil produces. Thus, Watts' work shows the instabilities of governmental projects, and he asserts that, 'my account of Nigeria reveals ragged, unstable, perhaps ungovernable, spaces and analytics of government that hardly correspond to the well-oiled machine of disciplinary and biopower' (2003: 26). These kind of insightful studies which examine how rule can go awry are invaluable - and too few and far between. This exploration of instability and compromise in rule is, I would argue, something which needs much more empirical attention.

Another drawback to using the framework of governmentality is often its inattention to difference. There are erasures and foreclosures in the way people can conceive of themselves, and the performance of different subjectivities are read as (un)intelligible differently. Judith Butler (1996) in particular takes Foucault to task for this. She questions his assertion that, through biopolitics, '[p]ower 
no longer recognizes death' (Foucault, 2003: 248), and uses the example of how AIDS has been discursively deployed to construct gay men as the bearers of death. Here we see that power is not only about the administration of life, as Foucault suggests, but also operates through the management of death for very particular subjects. While Foucault does indeed make note of this in his discussion of state racism, Butler's questioning of the certitude with which Foucault makes historical assertions is well placed. More interesting for my analysis, however, is that she goes on to note that Foucault did not pay enough attention to the very political work of exclusion, stating that 'oppression works not merely through the mechanisms of regulation and production but by foreclosing the very possibility of articulation' (1996: 68). Butler's critique asks us to think about the ways in which some subjectivities are rendered intelligible and some unintelligible, invisible and unsayable.

This might be made clearer through an example. In terms of environmental politics, there is a particular subject who becomes authorized to speak on behalf of the environment. In Bruce Braun's account of the environmental politics in Clayoquot Sound, British Columbia, he makes this point. By examining the media coverage on the protests, he sets his sights on a particular protestor, a young, white man who is seen dragged off in handcuffs from a tense blockade. Braun reflects:

\footnotetext{
Why is it this man, rather than someone else, who spoke for nature? What made it possible for protestors like him - predominantly white, middle-class professionals (or their children) to stand before the machinery of the forest industry and speak as nature's defenders in a region claimed by the Nuu-chah-nulth as their traditional territories? (Braun, 2002: 71)
}

Why indeed. Because the performance of this subjectivity cannot be disconnected from its social location. Certain narratives gain privilege in the environmentalist critique, while others are marginalized (Bourke and Meppem, 2000). Further, within this privileging is also a demarcation of what other subjectivities can become. Thus, for the First Nations in Clayoquot Sound, the prescribed option is to perform an anachronism - they must appear as the green/ecological Indian, connected and close to nature. A performance outside of this is rendered unintelligible: without meaning (Braun, 2002). Hence, the option of being a First Nations person and a logger is foreclosed as 'inauthentic' - prevented from articulation to use Butler's words. Thus, the First Nations subjectivity in environmentalism is often limited to a 'primitive' group whose inherent nobility and value is linked to their understanding of nature. Foreclosed is the possibility of talking about these Aboriginal peoples as complex and multiply identified, sometimes engaging in survival strategies in a racist and colonial world. Instead, they become defined as one thing: the lone voice of truth, the virtuous defenders of an environment that is being destroyed by the rapaciousness greed for resources. This connection of racialized and gendered peoples and the environment has a long history, and the ways in which certain bodies have been associated with nature is beyond the scope of this article. However, it is important to note that certain people are called upon to fulfill the role of those who 'care' about the environment and its protection, as it is remade into a new space of governmentality. And it is most often women, the poor and racialized people who are excluded, or sharply defined, within this regime (Luke, 2003).

Framed another way, we find the regulation in terms of some bodies which have been constructed as closer to nature and, alternately, those that are constructed as natural. Thus, Hannah's work on the formation of social statistics in nineteenth-century America indicates how biopower worked as a function of racism (as well as sexism, heterosexism, classism and so on) to normalize particular kinds of bodies and subjectivities:

Racism took shape at this point (racism in its modern, 'biologizing', statist form): it was then that a whole politics of settlement 
(peuplement), family, marriage, education, social hierarchization, and property, accompanied by a long series of permanent interventions at the level of the body, conduct, health, and everyday life, received their color and their justification from the mythical concern with protecting the purity of the blood and ensuring the triumph of the race. (Hannah, 2000: 21)

In this way, the census worked to organize the vision of the state and its citizens - recognizing some as natural inheritors of an emerging nation, and disappearing others. Michael Brown's work on the production of the closet shows how this functions today. In a chapter in Closet space (2000) on the census and governmentality written with Paul Boyle, they demonstrate the way that censuses obscure and erase queers in the USA and UK, which reinforces that naturalness of heterosexuality. In neither the American or British cases is there a question about sexual orientation, which of course defines the ways in which people can identify immediately. But Brown and Boyle argue that the disappearing of homosexuals is not only a function of omitting the question, but also how the data are analyzed, particularly in Britain where couples were recoded if they identified themselves as living with a partner of the same sex. Further, they assert that the census functioned by way of recognition in the USA, only rendering visible those gays and lesbians who lived as couples - obscuring a whole host of people who do not choose this lifestyle but nonetheless identify as queer. Lastly, via self-discipline, some queers chose not to identify for fear of homophobia. In the contributions of Hannah and Brown and Boyle, then, we see how governmentality normalizes, makes natural, and through this process makes visible certain kinds of people/subjects/citizens/agents. But simultaneously, governmentality can render other subjects as unnatural, abnormal, and occlude them from view.

This discussion of exclusion relates well to another critique of the governmentality literature. O'Malley et al. cogently argue that what is missing from the work on governmentality is the critical spirit that was present in Foucault's work. ${ }^{5}$ As Foucault asserted, his project was not simply an apolitical one: rather, 'the real political task in a society such as ours is to criticize the working of institutions which appear to be both neutral and independent; to criticize them in such a manner that the political violence which has always exercised itself obscurely thought them will be unmasked, so that one can fight them' (Foucault in Rabinow, 1984: 5). But, as O'Malley et al. have remarked, the use of this critical perspective has been devalorized in the governmentality literature. They argue that in evacuating social relations from its analysis of the political ... much of the governmentality work would seem to short-circuit its capacity to contribute to the formulation of a "progressivist" post social politics' (1997: 513). In doing so, the possibilities for constructing counternarratives and important critiques of governmentality seem precluded. And yet, I think this is one area in which governmentality literature, if imagined differently, could provide keen insights that disturb commonsense notions about power and resistance, and initiate a process of rethinking on how one might take up environmental issues, for example, in ways that pay attention to the how it operates as a field of power.

Finally, some of governmentality literature, while explicitly acknowledging the ways in which power is exercised from and across the social body, simultaneously roots a large portion of its empirical work in the state. For example, some geographers have taken up neoliberal decentralization to look at how regional authorities and local states produce new modes of rationality for governing. And these studies have been particularly fruitful for analyzing society/state interactions which are of key importance to understanding certain kinds of governmentality. But what of other kinds of questions? As Foucault asserts:

I don't want to say that the State isn't important, what I want to say is that relations of power, and hence the analysis that must be made of them, necessarily extend beyond the 
limits of the State. In two senses: first of all because the State, for all the omnipotence of its apparatuses, is far from being able to occupy the whole field of actual power relations, and further, because the State can only operate on the basis of other, already existing power relations. (Foucault, 1980: 122)

If the state is no longer the automatic seat of government, how are people governed in alternative sites? How do these sites become authorized? Through what techniques and practices? How does one examine the microphysics of power? How does the constitution of the self contribute to governmentality? These are questions I think which take note of the state but also go beyond it - bringing nongovernmental organizations, corporations, research institutions, the media and other actors into the challenge of tracing modern rule. These sites, I argue, are a particularly interesting terrain for more empirical research.

Despite the problems I have highlighted, I remain confident that governmentality is a useful notion for geographers. Indeed, I assert that critical human geographers are already equipped with the tools to remedy some of these problems and can offer a rethinking of the concept to make it broader and more attuned to the complex 'hows' of rule. In particular, geographers bring three things to governmentality: an analysis of spatiality, place and identity; an attention to scale; and a recognition of the imbrications of nature and culture.

With its concentration on space and place, geography always already considers the specificity needed to understand the ways in which rule is applied differently in different places. Power is enacted somewhere - not just as a metaphor but a spatial reality. Power works through institutions, governments, corporations and bodies that are material and particularly located. Thus, if we understand power as articulated and enacted in places, then a spatial analysis becomes key. By examining the ways in which places are made through economic, social, cultural, political and biophysical processes, a geographical analysis is well positioned to avoid some of the pitfalls of a monolithic application of governmentality theory. Moreover, this interrogation of how place matters can take into account the ways in which rule is shaped by contestation and slippage - operating in a distinct fashion within different political economies. Connected to the concern with specificity, the geographical focus on the production of place-based identity also presents an opportunity to make the project of governmentality more nuanced. In recognizing how social location matters in the construction of space and place, geography can talk about the ways in which different bodies are incorporated into governmentality differently (or not at all), answering Butler's critique of Foucault's original articulation. These considerations will furnish the governmentality literature with a more robust approach.

Some geographers have already conducted studies which pay attention to the spatial political geographies of government. For example, Moon and Brown's (2000) study of the remaking of the National Health System in Britain has shown how spatialized language became crucial to this process. By using the tropes of neoliberalism to construct the local scale as 'government free' and 'flexible, innovative and energetic' (2000: 70 ) the state put forward a spatial discourse that championed the local as a site autonomous from centralized control, while at the same time regulating it more intensely. This kind of governing at a distance is also evidenced in Painter's (2005) work on regionalism, where he demonstrates that the Regional Economic Strategies in England work on the same principles - supposed regional autonomy which is really increasingly controlled from the center. These cases indicate that space matters in governmentality, and the ways in which spaces and places are formed and managed through governmentality needs to be a key area of concern.

A scalar analysis will also prove (and indeed has proven) to be particularly helpful in attenuating some of the difficulties with the governmentality literature. Applying scale to 
notions of rule means that we can see the ways in which the body, the household, the region, the nation, and the globe are imbricated and mutually constituted by and through the operation of governmentality. This allows for empirical studies which consider the national state as but one source of rule, opening up the possibility to understand the interaction between different modalities of power in all kinds of sites. The geographical work on scale, by de-centering the nation state, allows for a more complex approach to exercise of power and the operation of rule. Hannah has been particularly astute in this regard. His work on the census has shown how this statistical device works to naturalize the nation - or, more properly, the census does not work only to measure what is contained within the nation, but works to make the space of the nation: 'In a real sense, modern nations have only existed and been governable as nations to the extent that the people, activities, and resources that make them up have been gathered together in the form of statistics and other surveys, and these representations collected at what Latour calls "centers of calculation" ' (Hannah, 2001: 517). Further, his attention to scale has led him to comment on how governmentality is more or less successful at different scales. He argues at the end of his book Governmentality and the mastery of territory in nineteenth-century America that governmentality at the national scale rarely achieves fruition, 'due not only to the vastly greater material and logistical difficulty national states face in controlling the minutiae of social activity through their territories, but also to the vastly more cumbersome and uncertain complex of institutions and practices through which any nationalscale program must be mediated on the way to implementation' (Hannah, 2000: 222). The analytical frame that scale provides allows scholars to embark on a more complex reading of how particular sites are made through practices and technologies of governmentality.

Finally, and perhaps most importantly for the argument put forward in this paper, the human geographer's deconstruction of the nature/culture dualism will bring new insights to the governmentality literature. The argument that culture is inextricably linked to what counts as nature - and that biophysical processes shape what is known as culture shows that geographers are always already questioning the self-evidence of statements about the environment and its problems. This means that geographers are well situated to examine how some accounts of the environment are made into the truth and by extension how this truth operates as a regime of power. Further, geography is alone in the social sciences in its consideration of the agency non-human nature. This will be particularly important to studies that employ green governmentality, as nature often does not operate according to culture's rules. How nature is enrolled in, performs and resists attempts at governmentality provide stimulating fodder for analyses of the slippages and interstices in governing.

\section{Conclusion: thinking about nature and power}

It is not a matter of emancipating truth from every system of power (which would be a chimera, for truth is already power) but of detaching the power of truth from the forms of hegemony, social, economic and cultural, with which it operates at the present time. (Foucault, 1980: 133)

This article has been an attempt to read the management of nature through the eyes of Foucault, donning his particularly insightful lens to take up how the saving of nature is a profoundly political project. Notions of governmentality allow geographers to ask different kinds of questions about the environmentalist critique, a process which might yield a fresh perspective in terms of how truth claims and disciplinary regimes are formed. By deploying notions around the circulation of power, biopolitics, and technologies of the self, I have attempted to show how these concepts can provide a strong basis on which to interrogate 
the self-evident virtuousness of environmentalism in particular, and the governing of nature more generally. However, I have also tried to point out that one cannot abandon a more critical perspective when entering this terrain. Instead, there needs to be an awareness of the ways in which governmentality literature needs to be made messier - more complicated - to provide a robust analysis of the exercise, administration and application of power. By paying attention to unintended consequences, acts of resistance, processes of occlusion, and multiple locations in the exercise of green governmentality, I think geographers can provide a more nuanced picture of how rule circulates, and, indeed, is changed by this circulation. In recognizing both the utility and drawbacks of governmentality as applied to nature, geographers are provided with the opportunity to rethink environmental politics in a way that might open up space to seize on the interstices provided in the administration of rule. Further, accepting that environmentalism is always implicated in power should not induce paralysis for the critical spirit (a critique often leveled at Foucault) but rather a sense of liberation. To me, the most compelling part of Foucauldian analysis is that, if things are made rather than found, then the possibility exists for them to be unmade, or made differently. If we accept Legg's (2005) notion that studies in governmentality operate as genealogical projects, charting the history of the present, this allows for the imagination of things - politics, natures, power relations, subjectivities, discourses, practices - to be otherwise. Once the claiming of innocence is recognized as a fiction, environmental politics can put aside its attempts to position itself outside of power. Perhaps part of our job as geographers then is to explore this fiction and build new ways of imagining human/non-human relations.

\section{Acknowledgements}

I would like to thank Steven Flusty, Paul Rutherford, Jocelyn Thorpe and Gerda Wekerle for their advice on this paper. Also, I would like to thank Alexander B. Murphy and the two anonymous reviewers who provided insightful comments and suggestions on an earlier draft that improved this paper dramatically.

\section{Notes}

1. The idea or reality of nature should never be taken for granted, and, as such, I have put this much-abused shorthand in scare quotes for its first usage in the article. As Donna Haraway reminds us, 'Nature cannot pre-exist its construction' (1992: 296). With this in mind, I will use the term throughout the course of this article, while recognizing it as contested and ambiguous. In deploying nature, I mean not only the biophysical processes which are generally understood to form the environment, but also ideas and imaginings of nature and wilderness, ideas about human nature, concepts of what is natural and unnatural, and human/non-human relations.

2. Disney has transformed itself into a veritable eco-funding agency with its Disney Wildlife Conservation Fund. Donating over 10 million dollars to 550 projects in 100 countries, Disney has supported environmental NGOs in both the North and Global South, zoos, and research institutions seeking to protect and preserve nature. The connections between the Disney corporation and research institutions, NGOs, governments and quasi-governmental organizations are multiple and capillary.

3. Foucault also takes this up in The order of things (2001) in Chapter 5 entitled 'Classifying'. It is here that he maps how natural history came to know and measure plant and animal species.

4. In particular, Katharyne Mitchell's (2003) account of the educational shift from the production of multicultural citizens to global cosmopolitanites is very compelling. She shows the way that changes in curriculum and educational discourse attempt to remake students as 'hierarchically conditioned, globally oriented state subjects' (Mitchell, 2003: 388).

5. Geographers like Mike Raco (2003) also echo this critique.

\section{References}

Agrawal, A. 2005: Environmentality: technologies of government and political subjects. Durham, NC: Duke University Press. 
Bäckstrand, K. 2004: Scientisation vs. civic expertise in environmental governance: eco-feminist, eco-modern and post-modern responses. Environmental Politics 13(4), 695-714.

Barry, A., Osborne, T. and Rose, N. 1996: Foucault and political reason. London: UCL Press.

Blake, L. 1999: Pastoral power, governmentality and cultures of order in nineteenth-century British Columbia. Transactions of the Institute of British Geographers NS 24, 79-93.

Bourke, S. and Meppem, T. 2000: Privileged narratives and fictions of consent in environmental discourse. Local Environment 5, 299-310.

Braun, B. 2000: Producing vertical territory: geology and governmentality in late Victorian Canada. Ecumene 7(1), 7-46.

- 2002: The intemperate rainforest: nature, culture and power on Canada's West Coast. Minneapolis: University of Minnesota Press.

Brown, M. and Boyle, P. 2000: National closets: governmentality, sexuality and the census. In Closet space: geographies of metaphor from the body to the globe, London: Routledge, 88-115.

Butler, J. 1996: Sexual inversions. In Hekman, S., editor, Feminist interpretations of Michel Foucault, University Park, PA: Penn State University Press, 59-75.

Cruikshank, B. 1996: Revolutions within: selfgovernment and self-esteem. In Barry, A., Osborne, T. and Rose, N., editors, Foucault and political reason: liberalism, neo-liberalism and rationalities of government, Chicago: University of Chicago Press, 231-51.

Darier, E. 1996: Environmental governmentality: the case of Canada's green plan. Environmental Politics 5, 585-606.

- 1999: Foucault and the environment. In Darier, E., editor, Discourses of the environment, Malden, PA: Blackwell, 1-33.

Dean, M. 1999: Governmentality: power and rule in modern society. London: Sage.

Demeritt, D. 2001: Scientific forest conservation and the statistical picturing of nature's limits in the Progressive-era United States. Environment and Planning D 19, 431-59.

Desbiens, C. 2004: 'Women with no femininity': gender, race and nation-building in the James Bay Project. Political Geography 23, 347-66.

Dobson, A. 1990: Green political thought: an introduction. London: Unwin Hyman.

Emel, J. 2002: An inquiry into the green disciplining of capital. Environment and Planning A 34, 827-43.

Ewald, F. 1991: Insurance and risk. In Burchell, G., Gordon, C. and Miller, P., editors, The Foucault effect, Chicago: University of Chicago Press, 197-210.

Foucault, M. 1980: Power/knowledge. New York: Pantheon Books.

- 1990: The history of sexuality: volume 1. New York: Vintage (originally published in English in 1978).
- 1991: Governmentality. In Burchell, G., Gordon, C. and Miller, P., editors, The Foucault effect, Chicago: University of Chicago Press, 87-104.

- 1994: The political technology of individuals. In Faubion, J., editor, Michel Foucault: power, New York: The New Press, 403-17.

- 1995: Discipline and punish: the birth of the prison (translated by A. Sheridan). New York: Vintage (originally published in 1977).

- 2001: The order of things. London: Routledge (originally published in English in 1970).

-2003: 17 March 1976. In Bertani, M. and Fontana, A., editors, Society must be defended: lectures at the Collège de France 1975-1976, New York: Picador, 239-64.

Gibson, K. 2001: Regional subjection and becoming. Environment and Planning D 19, 639-67.

Gordon, C. 1991: Governmental rationality: an introduction. In Burchell, G., Gordon, C., and Miller, P., editors, The Foucault effect, Chicago: University of Chicago Press, 1-51.

Greenpeace Canada no date: Tips for green living. Retrieved 18 November 2005 from http://www.greenpeace.ca/e/resource/green/

Hacking, I. 1990: The taming of chance. Cambridge: Cambridge University Press.

Hajer, M. and Fischer, F, editors 1999: Living with nature: environmental politics as cultural discourse. Oxford: Oxford University Press.

Hannah, M. 2000: Governmentality and the mastery of territory in nineteenth-century America. Cambridge: Cambridge University Press.

- 2001: Sampling and the politics of representation in the US Census 2000. Environment and Planning D 19, $515-34$.

Haraway, D. 1992: The promise of monsters: a regenerative politics for inappropriate/d others. In Grossberg, L., Nelson, C. and Treichler, P.A., editors, Cultural studies, New York: Routledge, 275-332.

Howell, P. 2004: Race, space and the regulation of prostitution in colonial Hong Kong. Urban History 31, 229-48.

King, Y. 1997: Managerial environmentalism, population control and the new national insecurity: towards a feminist critique. Political Environments 5 (Fall). Retrieved 13 March 2004 from http://www .dawn.org.fj/global/globalization/linkagesproject/ institute2003/preliminaryreaderdocs/ynestramag environmet.doc

Legg, S. 2005: Foucault's population geographies: classifications, biopolitics and governmental spaces. Population, Space and Place 11, 137-56.

Lemke, T. 2001: 'The birth of bio-politics' - Michel Foucault's lecture as the Collège de France on neoliberal governmentality. Retrieved 1 December 2004 from http://www.thomaslemkeweb.de/engl.\%20 texte/The\%20Birth\%20of\%20Biopolitics\%203.pdf 
Luke, T. 1996: Governmentality and contragovernmentality: rethinking sovereignty and territoriality after the Cold War. Political Geography 13, 491-507.

- 1997a: Ecocritique: contesting the politics of nature, economy, and culture. Minneapolis: University of Minnesota Press.

- 1997b: The World Wildlife Fund: ecocolonialism as funding the worldwide 'wise use' of nature. Capitalism, Nature, Socialism 8(2), 31-61.

- 1998: Ecocritique in context: technology, democracy and capitalism as environment. Paper presented at the IGCC/MacArthur Scholars Seminar on International Environmental Policy, Newport Beach, CA, 31 May to 1 June 1998, 1-27.

- 1999: Environmentality as green governmentality. In Darier, E., editor, Discourses of the environment, Malden, PA: Blackwell, 121-51.

- 2003: On the political economy of Clayoquot Sound: the uneasy transition from extractive to attractive models of development. In Magnusson, W. and Shaw, K., editors, A political space: reading the global through Clayoquot Sound, Minneapolis: University of Minnesota Press, 91-112.

MacKinnon, D. 2000: Managerialism, governmentality and the state: a neo-Foucauldian approach to local economic governance. Political Geography 19, 293-314.

Macnaghten, P. 2003: Embodying the environment in everyday life practices. The Sociological Review 51, 62-84.

Miller, P. and Rose, N. 1993: Governing economic life. In Gane, M. and Johnson, T., editors, Foucault's new domains, London: Routledge, 75-105.

Miller, T. 1993: The well-tempered self: citizenship, culture, and the postmodern subject. Baltimore: Johns Hopkins University Press.

Mitchell, K. 2003: Educating the national citizen in neoliberal times: from the multicultural self to the strategic cosmopolitan. Transactions of the Institute of British Geographers NS 28, 387-403.

Moon, G. and Brown, T. 2000: Governmentality and the spatialized discourse of policy: the consolidation of the post-1989 NHS reforms. Transactions of the Institute of British Geographers NS 25, 65-76.

Moore, D., Pandian, A. and Kosek, J. 2003: Introduction: the cultural politics of race and nature. In Moore, D.S., Pandian, A. and Kosek, J., editors, Race, nature and the politics of difference, Durham, NC: Duke University Press, 1-70.

Murdoch, J. and Ward, N. 1997: Governmentality and territoriality: the statistical manufacture of Britain's 'national farm'. Political Geography 16, 307-24.
Natural Resources Defense Council 2005: NRDC's guide to greener living: make 2005 the greenest year yet! Retrieved 18 November 2005 from http://www.nrdc.org/cities/living/gover.asp

O'Malley, P., Weir, L. and Shearing, C. 1997: Governmentality, criticism, politics. Economy and Society 26, 501-17.

Painter, J. 2005: Governmentality and regional economic strategies. In Hillier, J. and Rooksby, E., editors, Habitus: a sense of place (second edition), Aldershot: Ashgate, 131-57.

Peace, A. 2002: Governing the environment: the programs and politics of environmental discourse. In O'Farrel, C., editor, Foucault: the legacy, Proceedings of the Foucault: The Legacy Conference held in Australia, 1994, Kelvin Grove, QLD: University of Queensland, 530-45.

Philo, C. 2001: Accumulating populations: bodies, institutions and space. International Journal of Population Geography 7, 473-90.

Rabinow, P. 1984: Introduction. In The Foucault reader, New York: Pantheon Books, 3-29.

Raco, M. 2003: Governmentality, subject-building, and the discourses and practices of devolution in the UK. Transactions of the Institute of British Geographers NS 28, 75-95.

Renner, M. 2005: State of the world 2005: a Worldwatch Institute report on progress towards a sustainable society. New York: W.W. Norton.

Rose, N. 1996: Inventing our selves. Cambridge: Cambridge University Press.

Rutherford, P. 1999: The entry of life into history. In Darier, E., editor, Discourses of the environmen, Malden, PA: Blackwell, 37-62.

- 2002: Policing nature: ecology, natural sciences and bio-politics. In O'Farrel, C., editor, Foucault: the legacy, Proceedings of the Foucault: The Legacy Conference held in Australia, 1994, Kelvin Grove, QLD: University of Queensland, 546-62.

Scott, D. 1999: Refashioning futures: criticism after postcoloniality. Princeton, NJ: Princeton University Press.

Watts, M. 2003: Development and governmentality. Singapore Journal of Tropical Geography 24(1), 6-34.

- 2004: Resource curse? Governmentality, oil and power in the Niger Delta, Nigeria. Geopolitics 9(1), 50-80.

World Wildlife Fund U.S. no date: How you can help: at home, out shopping and in the garden. Retrieved 18 November 2005 from http://www.panda.org/how_ you_can_help/at_home/ 